\title{
Digital Image and Cinema
}

\author{
Alberto J. L. Carrillo e May Zindel
}

\section{Resumo:}

O novo cinema digital de Hollywood baseado na espetacularização a partir de computação gráfica levou os cineastas a trabalhar com equipes tecno-científicas concentradas no controle total da imagem, e é justamente a predominância da imagem que tende a simplificar os cenários cinematográficos. Esta simplificação parece rejeitar a velha idéia de que o cinema trata de "contar histórias por meio de imagens", em vez de emancipar a imagem da narrativa. Isto caminha lado a lado com uma nova sensibilidade que negligencia a narrativa e está centrada no entretenimento, apesar das queixas feitas por intelectuals. Com isto, o novo cinema digital baseado no espetáculo reabre sob novas circunstâncias uma polêmica poética fundamental com origem no debate entre a pintura abstrata e a pintura figurativa: quais são as possibilidades específicas de cada meio?

\section{Palavras Chave:}

poética, cinema digital, espetáculo, desnarrativização.

\begin{abstract}
:
The new Hollywood digital cinema centered in spectacularity on the basis of computer graphics, has driven the filmmakers to work with tecnoscientific teams concentrating in the total control of the image and it is exactly the predominance of the image that tends to simplify the cinematographic plots. This simplification seems to reject the old idea that cinema is "about telling stories through images", instead emancipating the narrative image. This goes side by side with a new sensibility that disregards the narrative and centers itself in entertainment, in despite of intellectuals' complaints. Thus, the new digital spectacular cinema reopens under new conditions a fundamental poetological polemic that had already a background in the debate about abstract painting and figurative painting: what are the specific possibilities of each media?
\end{abstract}

\section{Keywords:}

poetics, digital cinema, spectacle, denarrativization

Most theories of cinema focus on time. The dominant view on cinema is that it is about telling stories through images. The role of script in cinema seems to confirm such view, and the poetics of cinema has been strongly oriented according to literary criteria. Nevertheless, digital technologies seem to question the accustomed concept of cinema. Such technologies, extensively exploited by American film industry, seem to reduce cinema to spectacular and impressing visual effects, so that the plot increasingly loses its importance. Typical Hollywood productions have plots, which seem to be irrelevant, and such films consist of short spectacular «sequences». In those sequences time loses importance as the dimension of a «meaningful» event and it becomes the dimension of a «spectacular one». Digital image processing in cinema strongly fosters this shift from the «meaningful» to the mere «spectacular», but with this shift the imagery turns out to be the real nature of cinema. Imagery as such, as Lessing (1965) noted in his «Laokoon», lies in the simultaneous or synchronic and out of the temporal sequence. In other words, in discarding meaningful sequences, the increasingly spectacular character of cinematic images tends to flatten cinematic time. We could call this 
phenomenon the «digital compression of cinematic time», a compression fostering expressive planarity in cinema. Could we now say that cinematic time is essentially flat, and any attempt to tell stories through or in cinema is a mistake concerning the nature of the medium as an imaginal one? Does this imply that cinema is basically spectacular? The aim of this presentation is to briefly address such questions.

\section{The Mosaic or Flat Character of Cinema in General}

The most obvious difference of film as compared with photography is the so-called "moving-image". In remembering Lessing's distinction in his «Laokoon» (1965) between painting and literature on the basis that the elements of painting are juxtaposed, whereas the elements of narrative are successive, cinema looks indeed as seemingly hybrid. That appears quite clear in expressions like "motion pictures" or "time based medium". No wonder that most cinema theories focus on time. But time or succession, as Lessing states, is the medium of literature, so, theories of cinema stressing time, tend to strongly rely on literary criteria. Nevertheless, the rise of computer animated graphics and, in general, the digital processing of images seems to create a quite new situation, practically and, thus, theoretically.

Nowadays there is a new film genre, a major one, to which these movies belong: «War of the Worlds» (2005), «Mission: Impossible III» (2006), «Spiderman 3» (2007), «300» (2007), «Die Hard» (2007) and «Transformers» (2007). Arresting, impressive visual effects and mostly overall sustained spectacularity characterize movies of this kind. In fact, such genre is becoming the indisputable majority of the so-called blockbusters. They are the most important part of the cinematic «entertainment» industry. Such movies do really have a plot but, in the end, either it is quite simple or it is completely irrelevant. Still images, even the spectacular ones, are literally flat. Lessing's criterion is true of them: their elements are merely juxtaposed; they contain absolutely no narrative. On the other hand, the spectacular movie sequences are, to be sure, sequences, but their narrative content plays almost no role. They are a kind of "cultural content" (LASH, 2002: 68) which, as Scott Lash points out, “(...) leaves no time for reflection (...)” (LASH, 2002: 18). This must be stressed when assessing the nature of the new spectacular movie genre.

Spectacular movie sequences are so arresting that the plot becomes irrelevant, no matter how intricate it may be. Let us suppose that the plot of the film is a complicated and subtle one. At any rate, the complexity of cinematic plot fades as compared to literary narrative in general. Furthermore, the complexity of literary narrative demands a special kind of public, a public that under the fast changing conditions of the industrial and urban life vanishes. Poetry, literary narrative and scientific treatises demand, as Scott Lash states, "(...) conditions of reflection necessary for engaging with (...)" (LASH, 2002: 74) them. Yet, already Benjamin thematized the changed "receptiveness" (BENJAMIN, 1977: 185) for poetry by the middle of the 19th century. He blamed the new industrial and urban life for weakening "willpower" (BENJAMIN, 1977: 185), "capacity of concentration" (BENJAMIN, 1977: 185) and "interest" (BENJAMIN, 1977: 185) necessary for engagement with "lyrical poetry" (BENJAMIN, 1977: 185). According to Benjamin, “(...) art demands concentration from the beholder" (BENJAMIN, 1977: 166). But just the rapid new] «Sammlung»[ urban life (BENJAMIN, 1977: 198) generated the need for "mass dissipation" (BENJAMIN, 1977: 166), the business of the so-called «entertainment industry». Entertainment substitutes reflection and concentration. Echoing Benjamin, Lash certain pace of movement (...) is conducive to (...) narratives (...).]a[says that " Just about the right time for reflection" (LASH, 2002: 18). But new echnological forms of life" (LASH, 2002: 18) starting with industrialization]t[“ “(...) are too fast for reflection and too fast for linearity (...)” (LASH, 2002: 18) proper to narrative.

Following the tread of Benjamin's argumentation, the new social life generates a kind of "experience modified in its structure" (BENJAMIN, 1977: 186). The change can be exemplified by newspaper. It rapidly displaced books becoming the most widespread reading material, but the "principles of newspaper information" (BENJAMIN, 1977: 18) are, Benjamin points out, "newness, brevity, understandability, and, 
«above all, disconnectedness» of the individual news of each other (1)" (BENJAMIN, 1977: 188). Interesting here is that McLuhan considers newspaper as having a "mosaic" structure, such a structure is "discontinuous, abrupt, and multileveled" (MCLUHAN \& MCLUHAN, 1988:55). McLuhan stresses the "two-dimensional" (MCLUHAN \& MCLUHAN, 1988: 55) character of the "mosaic form" (MCLUHAN, 1998: 334). But, remember Lessing, two-dimensionaliy or flatness is proper to images and just the contrary to narrative. In other words, the incoherence and disconnectedness of news make of the newspaper something more like an image than a discourse or narrative. The predominance of newspaper over books is in this sense a regress to «imaginal», or as McLuhan calls them, "pre-literate" (MCLUHAN, 1998: 11) conditions of communication. But newspaper is by no means an isolate phenomenon.

As is generally known, Benjamin takes cinema as the paradigmatic medium evincing the modified structure of experience in the new, fast urban life. Benjamin compares the canvas with the cinematic screen, and says that the canvas "(...) invites the beholder to contemplation; he can abandon himself to the flow of his own associations. In front of the cinematic image he cannot do that. As soon as he looks at it, it has already changed. It cannot be locked into its position" (BENJAMIN, 1977: 164). Obviously, the flow of cinematic images beats by far the "brevity" (BENJAMIN, 1977: 188) proper to news. A little bit later Benjamin quotes Duhamel, who says: "I cannot anymore think what I want. The moving images take the place of my thoughts (...)" (BENJAMIN, 1977: 164), and Benjamin goes on noticing that "(...) indeed, the change of images breaks at once the beholder's flow of associations" (BENJAMIN, 1977: 164). The point is not only the fast changing images, but also their relationship with each other. The image created by the painter is, says Benjamin, "(...) a whole image, whereas the cameraman's image is manifoldly fragmented (...)" (BENJAMIN, 1977: 158). This is a kind of fragmentation that compared to the total character of a painting reminds us of the "mosaic form" of newspaper (McLuhan) or of the "disconnectedness" of the individual news. In this sense, and comparing now with theatrical ompetent observers have already noted that]c[performance, Benjamin says that " in cinematographic performance "the best impression is mostly achieved when he]t[acting is reduced to a minimum (...)" (BENJAMIN, 1977: 152). In fact, " theatrical actor on stage puts himself in a role. That is forbidden for the cinematographic actor. His achievement is definitely not a unitary one, but it is composed by many isolated achievements" (BENJAMIN, 1977: 153). In other words, as compared to the theatrical performance, the cinematographic one is affected by "disconnectedness" (BENJAMIN, 1977:188) as news are disconnected from each other as compared with the content of a book. Indeed, «cinematographic montage» shows in principle the traits of what McLuhan calls "mosaic form," namely, out of necessity it is "discontinuous, abrupt, and multileveled". Due to montage, cinematographic performance is in principle nothing but a mere juxtaposition (remember Lessing again) of more or less heterogeneous elements. Cinema itself is, from this point of view, flat in spite of its obvious temporal dimension, that is, the degree of complexity shown by its narrative elements does not matter.

\section{The Mosaic Character of Cinema under Digital Conditions}

If under industrial and urban conditions, proper to that what McLuhan called the "mechanical age", (MCLUHAN, 1998: 9) the "pace of movement" (LASH, 2002: 19) was already "too fast for reflection" (LASH, 2002: 19) substituting «entertainment» for reflection, under digital conditions the situation becomes much more apparent.

Following Benjamin and McLuhan, Scott Lash stresses the speeding-up of communication due to radio, telegraph, telephone, television, and, above all, computer (LASH, 2002: 68). Lash focuses on the "duration" (LASH, 2002: 68) of their "cultural contents" (LASH, 2002: 6). It is in principle "ephemeral" (LASH, 2002: 72), and the mark of such "ephemerality" (LASH, 2002: 72) is just that it is accessed mainly "in real time" (LASH, 2002: 69). This idea can be reformulated in McLuhanian terms. The "message" of such media is not their "cultural content" - what is seen, said, heard, written or read by means of them - but their "(...) power (...) to «reshape» any lives that they touch" (MCLUHAN, 1998: 52). The reshaping power is determined by 
the real time nature of such -up,]ing[media. Real time speeds up communication and in such a "(..) speed culture becomes ephemeral. The monument lasts for centuries, if not millennia, the novel for generations; a scholarly book a decade. The newspaper article has value just for a day. The pyramids took centuries to build; the scholarly discourse of a treatise - entailing reflection - takes, some people say, four years. The newspaper report on the latest soccer match must be written and wired within 90 minutes after the match. This leaves no time for reflection (...)" (LASH, 2002: 18).

But the "ephemerality" in point correlates with a «reshaped structure» of reviously the media content was narrative or]p[experience. As Lash puts it, “ lyric and surely a 'deep meaning' (...). The question is whether this new content [the cultural content accessed "in real time"] (...) can yield existential meaning, as once did epic poem or novel (...), (...) clearly it cannot" (LASH, 2002: 70). Communication "in real time" is the most salient side of the "(...) short duration culture [but it] started of course with the newspaper. It printed «news»" (2). (...) Newspapers are connected with time, with instantaneity of a sort" (LASH, 2002: 73). Real time is the radical expression of a cultural content, which "(...) not only does not endure, but is constantly new. Indeed the content is «so» new that there is no time for re-presentation (...)" (LASH, 2002: 73), that is, for "reflection" (LASH, 2002: 19). But real time is the extreme case of that "ephemerality" already addressed by Benjamin in the case of newspaper as a medium weakening "concentration". In general, technology such as "television, newspaper, and digital media - (...) does not work through discourse. It has no time for discoursing" (LASH, 2002: 74). Referring to such media and to the "brute facticity of their messages" (LASH, 2002: 74) Lash says that "[y]ou read them, just woken up, in the morning paper at the breakfast table; hear them while attending to the baby, on the six o'clock evening new; or listen to them struggling through a traffic jam on the way to work, on the car radio. You receive them under conditions of «distraction» and not under the conditions of «reflection» necessary for engaging with discursive argument" (LASH, 2002: 74). Those media are just not "[d]iscursive media, like the academic article or book, [which] work through reflection and argument" (LASH, 2002: 74). The exposure to such media necessarily effects what McLuhan calls a "psychic training" (MCLUHAN, 1998: 84) against "concentration" (Benjamin) and, especially, against "propositions, statements, organized in frameworks of concepts supported by legitimating argument" (LASH, 2002: 74). That is a training against "narrative" and "discourse" (Lash).

Like newspaper, cinema does not work "in real time" - neither much of TV content, nor recorded radio talks - but decisive here is the fast movement of disconnected image sequences. The result: "A movie like «Lethal Weapon 4» (...) is viewable not through the «concentrated» 'gaze' [remember Benjamin about weakened concentration], but through the 'glance' under conditions of «distraction»" (LASH, 2002: 69). Both the "glance" as «form of perception», and "distraction" (LASH, 2002: 69) as «structure of consciousness» are, certainly, the contrary to discursive reception through concentration and "legitimating argument" (LASH, 2002: 74). Furthermore, "[i]t is indeed the «content» of the information media that is ephemeral - whether in newspapers, on television, the Internet, telephony, or the branded products of fast-moving consumer goods" (LASH, 2002: 7). Of course, even if the content is not accessed "in real time," Hollywood's blockbusters are paradigmatic of "branded (...) fast-moving consumer goods" (LASH, 2002: 72) of the entertainment industry.

Now we come back to the hypothesis that a particular movie can have a subtle and intricate narrative content. If that is the case, montage implies discontinuities and abrupt changes of many kinds, and specially, different levels; thus, film accuses the "mosaic form" thematized by McLuhan. Furthermore, the pace of images is always "(...) too fast for reflection and too fast for linearity (...)" (LASH, 2002: 18) proper to narrative. But if that is already the case with film traditionally considered as narrative, the situation is much more clear in the case of the latest, digitally processed blockbusters. As John omputer animated graphics have enabled]c[Belton has already stated in 2002, " filmmakers to realize fantasy in a way that was only dreamed of a few years ago" (BRAUDY, et al., 2004: 902). That was true already in 2002; it is clear that the newest blockbusters are more than ever a mixture of "special effects and fantasy" (BRAUDY, et al., 2004: 906) based on computer-animated graphics. So, today it seems reasonable to think about a qualitative change in the 
status of montage: it is to a great extent - in some films completely - digital animation.

Those montages constitute the arresting and spectacular short sequences enthralling millions of spectators all over the world, and it must be noticed that after a few days most people cannot narrate those films, but nevertheless they still remember many impressive images. A clear logic underlies such a situation. Digital filmmakers take the greatest care about images leading to the spectacular sequences. Their main task lies in totally controlling the image and this just means, that the story loses importance as never before. In the age of digital imaging the story of a film is nothing more than an excuse for generating impressive computer graphics. We have already seen that according to Benjamin the image created by the painter is, "(...) a whole image, whereas the cameraman's image is manifoldly fragmented (...)," and Benjamin immediately goes on by saying that "(...) its fragments are put together in concordance with a new " (BENJAMIN, 1977: 158).] as compared with the elements of a painting[lawfulness Under digital imaging the "new lawfulness" (BENJAMIN, 1977: 158) for assembling the disconnected elements of montage is almost nothing more than newness and spectacularity. The very law for composing the cinematic "mosaic" under digital conditions is spectacularity and impressiveness. That is the task of «total digital control over the image». Narrative becomes a mere ghost. But that means that new digital cinema is essentially flat. Time has no real role to play in it, but this flies in the face of most theories of cinema and raises again the problem of the poetics of cinema and brings us back to Lessing.

\section{Conclusion. Lessing and the Poetics of Digital Cinema}

In his Laokoon Lessing (1965) pointed out the radical difference between painting and literature on account of their temporal structures: painting implies synchrony or simultaneity of their elements, whereas literature relies on diachrony or temporal succession. Lessing's trailblazing remark wiped out the traditional thesis «ut pictura poiesis» and the related idea of literature as "painting through words". For the first time it became clear that there is no general poetics but that the poetics of an art depend on that art's media. On the other hand, the temporal element in cinema has lead to consider it a kind of narrative. Cinema has mainly been thought of as "telling stories through images". But, if compared to narrative, proper cinema has never left "time for reflection" (Lash), modern cinema relies on impressive and spectacular computer graphics. Movies are not shorter than before, but new digital based cinema is not telling stories using images; it is mainly about imaging.

Digital imaging compresses the temporal dimension of cinema and reduces it to spectacularity and newness, and, thus, to a quasi-flat or non-narrative medium. It could be that with help of computer graphics Hollywood has understood the real poetics of cinema. If this is true, McLuhan is right in saying that intellectuals, that is, literary trained people, strongly tend to misunderstand the nature of new media. They cannot understand their "mosaic form," they cannot understand the structural flatness of new media. In particular, they have misunderstood the flat nature of cinema. If intellectuals are not looking for entertainment but for "deep meaning," they should not look at movies but they should read books and engage with sentences and arguments. They should not try to fight against the flat, superficial character of movies. They should take it easy and enjoy the superficial. The only refuge against the flat character of new media lies in writing and reading novels, treatises, and academic papers.

\section{Bibliografia:}

BENJAMIN. Illuminationen, Ausgewählte Schriften (1955). Frankfurt/M: Suhrkamp Verlag, 1977.

BRAUDY, LEO \& COHEN, MARSHAL. Film Theory and Film Criticism (1974). New York: Oxford University Press, 2004. 
GREENBERG, Clement. Art and Culture. Critical Essays (1961). Boston: Beacon Press Books, 1909.

LASH, Scott. Critique of Information. London: Sage Publications Ltd., 2002.

LESSING, Gotthold Ephraim. "Laokoon”, en: Werke in sechs Bänden, Schriften zur Antiken Kunstgeschichte, Band 5. Zürich: Stauffacher-Publishers Ltd., 1965.

MCLUHAN, Marshall. Understanding Media. The Extensions of Man (1964). Cambridge: MIT Press, 1998.

MCLUHAN, Marshall \& POWERS, Bruce R. The Global Village, Transformations in World Life and Media in the 21st Century. New York: Oxford University Press, 1989.

MCLUHAN, Marshall \& MCLUHAN, Eric. Laws of Media. The New Science (1988). Toronto: University of Toronto Press, 1999.

\section{Notas:}

(1) Our underlying.

(2) Emphasis from Lash.

\section{Mini Currículo :}

Alberto J. L. Carrillo Canán is Doctor professor at Benemérita Universidad Autónoma de Puebla (México). E-mail: acarrillo_mx@prodigy.net.mx

May Zindel is graduated at Unarte and Professor at Benemérita Universidad Autónoma de Puebla (México). E-mail: zindel007@ hotmail.com 